Sains Malaysiana 49(6)(2020): 1323-1332

http://dx.doi.org/10.17576/jsm-2020-4906-10

\title{
Effect of Neuro-Dynamic Technique on Repetitive Inward Ankle Rolls among Young Malaysian Athletes - A Randomized Controlled Trial
}

(Kesan Teknik Dinamik-Neuro pada Gulungan Dalaman Pergelangan Kaki yang Berulang Kali dalam Kalangan Atlet Muda Warganegara Malaysia - Ujian yang Dikawal Secara Rawak)

\author{
VINODHKUMAR RAmALINGAM*, VisWANATH SUndAR \& SAJU JOSEPH
}

\begin{abstract}
Inversion ankle sprains (IAS) are the most common injuries in sports and recreational activities. Incomplete rehabilitation among injured athletes may result in repetitive inward ankle rolls. Furthermore, inversion ankle sprain causes damage to the superficial peroneal nerve during repeated ankle inversion and plantar flexion. This results in positive neurodynamic tests in patients with sprained ankles. The purpose of this study was to find the effect of the neuro-dynamic technique on repetitive inward ankle rolls and compare it with standard physiotherapy on dynamic balance, pain score, peroneal longus, and tibialis anterior muscle activation response, knee range of motion (ROM), and functional ankle disability index (FADI) among young Malaysian athletes. Fourteen participants of age ranging from 17 to 35 years with repeated ankle sprains were recruited and randomized into Intervention Group A (Neurodynamic technique and Standard Physiotherapy-NDT+SP) and Intervention Group B (Standard Physiotherapy-SP). The participants of group A received NDT $(4 * 30 \mathrm{~s}$ with 1-min rest) consisting of peroneal nerve mobilization began the day after the baseline and continued through the week for 3 sessions. In addition, the participants received standard physiotherapy (pain management and exercise) whereas the group B participants received only standard physiotherapy. The participants with repeated IAS were checked for FADI followed by pain score, dynamic balance (Y-balance), and knee ROM (using electro-goniometer). The peroneal longus and tibialis anterior muscle activity response was tested by Surface Electromyography (sEMG) (Noraxon Myo-Muscle) on the injured leg. The subjects of the two groups were tested on selected variables in baseline, mid, post and follow-up measurements. Repeated Measures Analysis of Variance (ANOVA) was computed to determine the interaction effects of time and between-subject factors. ANOVA results $(N D T+S P)$ indicated that dependent variables $F A D I(F(1.148,36)=4701.14)$, pain score $(F(1.98,36)=$ $132.697)$, dynamic balance $(F(1.409,36)=16.42)$, knee $\operatorname{ROM}(F(1.498,36)=62.232)$, peroneal longus peak activity $(F(3,36)=25.727)$, and tibialis anterior peak activity $(F(3,36)=17.563)$ had a significant effect $(p<0.05)$ within the times of intervention among participants. Based on the post hoc test. FADI, pain score and knee ROM showed consistent improvement in intervention over the injured leg. The findings of this study show improvement in dynamic balance, pain score, peroneal longus and tibialis anterior muscle activation response, knee ROM, and FADI in both groups. The neurodynamic technique together with standard physiotherapy intervention shows safe and similar effects between variables. As part of the ankle rehabilitation protocol, it also recommends the neurodynamic technique to prevent repetitive IAS.
\end{abstract}

Keywords: Ankle injury; physiotherapy (techniques); range of motion; surface electromyography; visual analogue pain scale

\section{ABSTRAK}

Kecederaan terseliuh songsang pada pergelangan kaki (IAS) adalah kecederaan yang paling biasa dalam aktiviti sukan dan rekreasi. Pemulihan yang tidak menyeluruh dalam kalangan atlet yang tercedera boleh mengakibatkan gulungan dalaman pergelangan kaki yang berulang kali. Tambahan lagi, terseliuh songsang pada pergelangan kaki menyebabkan kerosakan pada saraf peroneal semasa gulungan dalaman pergelangan kaki yang berulang kali dan fleksi kaki. Ini menyebabkan ujian neurodinamik yang positif pada pesakit yang terseliuh pergelangan kaki. Tujuan kajian ini adalah untuk mengetahui kesan teknik neuro-dinamik pada gulungan dalaman pergelangan kaki yang berulang kali dan membandingkannya dengan fisioterapi yang standard pada keseimbangan dinamik, skor nyeri, peroneal longus dan respon pengaktifan otot tibialis anterior, julat pergerakan lutut (ROM) dan indeks kecacatan pergelangan kaki yang berfungsi (FADI) dalam kalangan atlet muda warganegara Malaysia. Empat belas peserta berumur antara 17 hingga 35 tahun dengan pergelangan kaki terseliuh yang kerap dipilih dan dirawakkan kepada Pengantaraan Kumpulan A (teknik neuro-dinamik dan fisioterapi standard-NDT + SPT) dan Pengantaraan Kumpulan B (fisioterapi standard-SP). Peserta Kumpulan A mendapat NDT (4*30 s dengan 1-min rehat) yang terdiri daripada mobilisasi saraf peroneal bermula sehari selepas garis dasar dan berterusan sepanjang minggu selama 3 sesi. Di samping itu, peserta mendapat fisioterapi standard (pengurusan kesakitan dan senaman), manakala peserta Kumpulan B hanya menerima fisioterapi 
standard. Para peserta dengan IAS yang berulang kali diperiksa diikuti dengan skor nyeri, keseimbangan dinamik (keseimbangan-Y) dan lutut ROM (menggunakan elektro-goniometer). Respons peroneal longus dan pengaktifan otot tibialis anterior diuji dengan menggunakan Permukaan Elektromiografi (sEMG) (Noraxon Myo-Muscle) pada kaki yang cedera. Subjek daripada kedua-dua kumpulan diuji pada pemboleh ubah yang terpilih dalam pengukuran garis dasar, pertengahan, pasca dan susulan. Ukuran Analisis Varians yang Berulang Kali (ANOVA) telah dikira untuk menentukan kesan interaksi masa dan faktor antara subjek. Keputusan ANOVA (NDT + SP) menunjukkan bahawa pemboleh ubah bersandar FADI $(F(1.148,36)=4701.14)$, skor nyeri $(F(1.98,36)=132.697)$, keseimbangan dinamik $(F(1.409,36)=16.42)$, lutut $\operatorname{ROM}(F(1.498,36)=62.232)$, aktiviti puncak peroneal longus $(F(3,36)=25.727)$ dan aktiviti puncak tibialis anterior $(F(3,36)=17.563)$ mempunyai kesan yang signifikan $(p<0.05)$ dalam masa intervensi dalam kalangan peserta. Berdasarkan ujian pasca hoc. FADI, skor nyeri dan ROM lutut menunjukkan peningkatan yang berterusan dalam pengantaraan pada kaki yang cedera. Hasil kajian ini menunjukkan peningkatan keseimbangan dinamik, skor nyeri, respons pengaktifan peroneal longus dan otot tibialis anterior, ROM lutut, dan FADI pada keduadua kumpulan. Teknik neuro-dinamik bersama dengan pengantaraan fisioterapi standard menunjukkan kesan yang selamat dan serupa antara pemboleh ubah. Sebagai sebahagian daripada protokol pemulihan pergelangan kaki, teknik neurodinamik juga disyorkan untuk mencegah IAS yang berulang.

Kata kunci: Analog skala sakit boleh nampak; fisioterapi (teknik); julat pergerakan; kecederaan pergelangan kaki; permukaan elektromiografi

\section{INTRODUCTION}

Inversion ankle sprains (IAS) are common among athletes ranging from 15 to $45 \%$. The recurrence of chronic ankle instability (CAI) has been reported by $10-30 \%$ (Bullock-Saxton 1995). A combination of inversion and foot adduction in the plantar flexion position is the most common injury mechanism in the ankle (Hertel 2002). This injury mechanism causes damage to the lateral ligaments of the ankle which shows repeated functional instability (FAI) in jumping and landing sports (Coughlan \& Caulfield 2007; McKeon \& Mattacola 2008). Additionally the study by Oda et al. (2019) and Malliaropoulos et al. (2009) reported ankle injuries are common among female football players and elite track $\&$ field athletes, respectively. McKay (2001) reported the occurrence of ankle injuries among the athletes is five times more than non-injured athletes. The dominant ankle joint (Türker et al. 2016) and supinated foot of the athletes are the intrinsic factors that produce FAI. In addition, the post-injury imbalance between invertor and evertor muscle deviates the center of pressure in the FAI foot towards laterally in standing (Hopkins et al. 2012) and in an inadequate rehabilitation (Murphy et al. 2003). Due to the innocuous nature of this injury, many individuals, perhaps as high as $55 \%$, do not follow a rehabilitation program designed by a healthcare professional (Wikstrom et al. 2013). Therefore, the actual incidence of IAS may, in fact, be significantly higher. The study reported $28 \%$ of ankle injuries in Malaysian badminton players between 18 and 25 years of age (Shariff et al. 2009) and another study by (Türker et al. 2016) reported that athletes under 20 years of age were quite susceptible to injury. FAI influences the disturbed neurophysiological response of the central nervous system that causes ankle giving-way sense in functional activities. Besides, the altered excitability of muscle groups proximal to the ankle propose the changes in motor function of higher brain centers (Wikstrom et al. 2013). It is believed that common peroneal nerve undergoes friction injury in fibular tunnel with excessive strain during inversion ankle sprain (IAS). This peripheral nerve is highly resistant in proximal joint movement that reduces the knee range of motion (ROM) (O’Neill et al. 2007; Pahor \& Toppenberg 1996).

Traditionally, athletes with repeated IAS were not treated with the Neurodynamic technique (NDT). The standard physiotherapy (SP) protocols commonly used to treat ankle injuries were exercise, ultrasound, cold and/ or heat (Mattacola \& Dwyer 2002). Recently, application of NDT in the clinical setting has emerged as an adjunct to pain syndrome assessment and treatment by reducing the nerves' physical 'pressure' (Ramalingam et al. 2018). The need of a particular neurodynamic technique (NDT) to prevent recurrent ankle injury by affecting the mechanoreceptor response of the ankle ligaments in athletes is presently lacking in the phase of rehabilitation (Garrick \& Requa 1988; Gutierrez et al. 2009). The NDT technique is applied effectively to improve ROM in conditions of hamstring flexibility (Castellote-Caballero et al. 2014) and peroneal nerve paralysis (Villafa et al. 2013). Additionally, literature demonstrates that NDT helps to facilitate relative movements between nerves and neighboring tissues, decreasing nerve adherence, assisting in the diffusion of noxious fluids and improving neural vascularity after the intervention (Coppieters et al. 2001). Thus, the purpose of the study is to find the effect of Neurodynamic Technique and Standard Physiotherapy on dynamic balance, pain score, peroneal longus and tibialis anterior muscle activation response, knee range of motion (ROM) and functional ankle disability index (FADI) among young Malaysian athletes. 


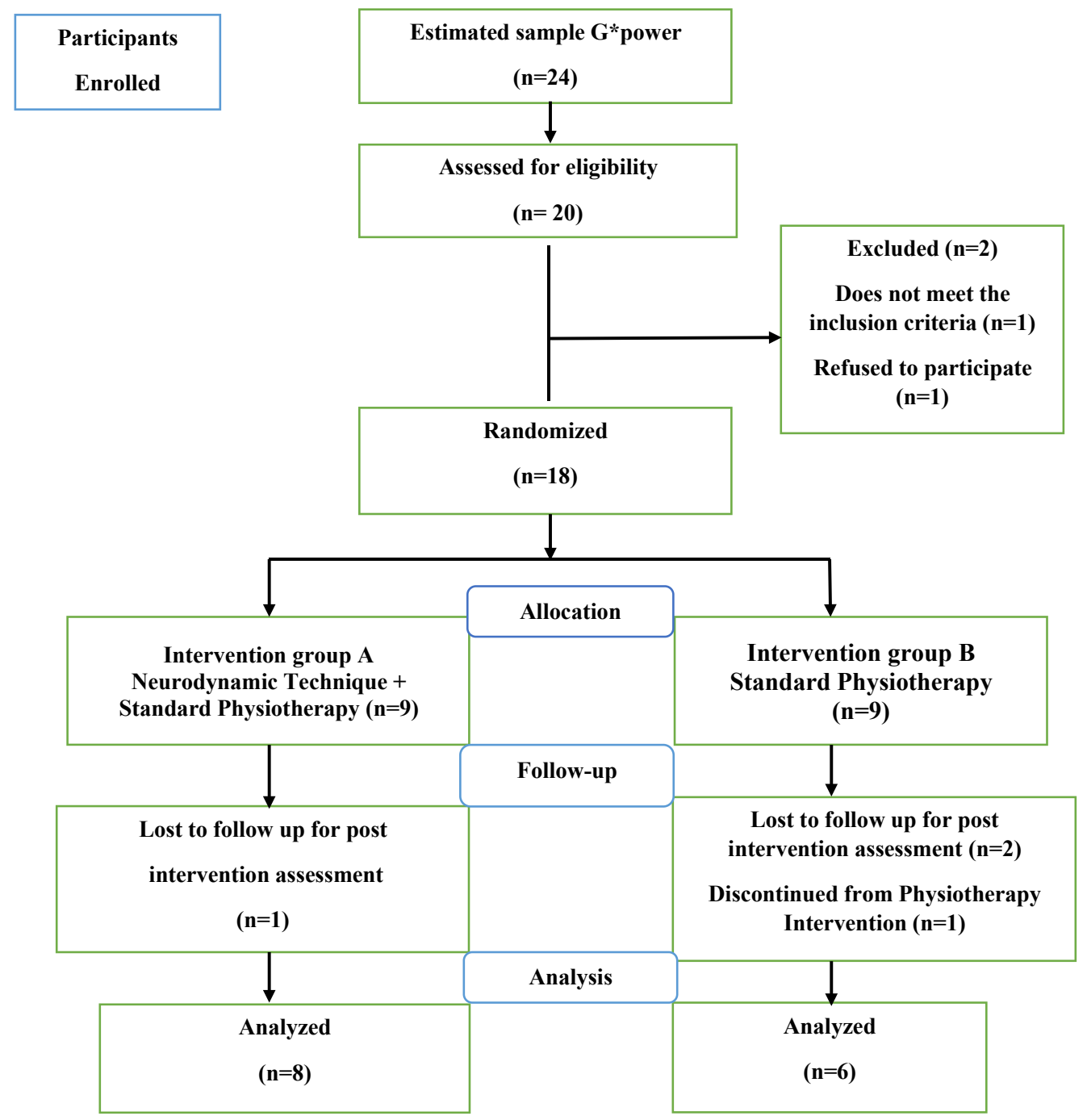

FIGURE 1. Consort flow diagram

\section{MATERIALS AND METHODS}

The randomized controlled trial was conducted in the Department of Biomechanics, National Sports Institute of Malaysia and Physiotherapy Centre, INTI International University Malaysia. The study was conducted for one year from December 2017 to December 2018. Based on $G^{*}$ Power F-test sample size calculation, participants $n=24$ were estimated. However, only 20 participants met the eligibility for the trail. Participants those who fulfilled the criteria were randomly divided into (Group A, $\mathrm{n}=$ 8) NDT + SP and (Group B, n=6) SP (Figure 1). Ethical clearance was obtained from the University Ethics Committee of INTI International University, Malaysia. Participants in both the intervention groups were blinded in this trial to minimize the bias. The participants were questioned on the number of ankle inversion sprains and its mechanism, previous injury report, and then the sports medicine doctors clinically confirmed that all the participants have repetitive lateral ankle sprain before recruiting in the study. The participants who met with the inclusion criteria, such as ankle 'giving way' sensations while playing, 4 weeks from the time of present injury and ankle instability within one-year duration, were asked to sign the informed consent form to participate in this trial. The participants who encountered other lower leg injuries in the past year and those who underwent surgery were excluded. A consultant in Sports Medicine Centre who was not associated with this trial was involved in generating computerized random number to assign the participants into the respective groups. The participants' functional instability was addressed by using the FADI sports module to determine their disability and the 
same tool was used to monitor the participants' progress in the baseline, mid-intervention (end of 3rd week), post-intervention (end of 6th week), and the follow-up (end of 12th week) session. The pain score, dynamic balance, knee ROM, peroneal longus (PL) and tibialis anterior (TA) muscle activity response and FADI from all the participants were measured during baseline, midintervention, post-intervention and follow-up.

\section{ASSESSMENTS}

Dynamic balance was measured by using Y Balance Test Kit $^{\mathrm{TM}}$ (Shaffer et al. 2015). Participants were instructed to stand on injured leg, and bend the hip, knee and ankle joint of the non-injured leg towards forward, posterolateral, and posteromedial along the balance stick with the non-injured leg. The participants were also instructed to return to their starting position without pushing their foot off and without losing their balance.
Active knee extension range of motion was measured with neutral ankle joint by using the twin axis electrogoniometer in a slumped spinal posture. The peak and mean muscle activation response of peroneus longus and tibialis anterior was recorded by a Noraxon wireless sEMG system in $2 \mathrm{~km} / \mathrm{h}$ walking speed (Ramalingam et al. 2018).

\section{NEURODYNAMIC TECHNIQUE}

The participants in the Intervention Group A underwent a six-week NDT, which consists of mobilization of the peroneal nerve, which was commenced on the next day after the first examination and continued for 3 sessions during the week. At each session, NDT was applied to the involved leg 4 times for a 30-s period with a 1-min pause between each application (Ramalingam et al. 2018). Movements of the NDT performed in supine position are shown in Table 1.

TABLE 1. Six weeks - Neuro-dynamic technique (NDT)

\begin{tabular}{ll}
\hline \multicolumn{1}{c}{ Week } & \multicolumn{1}{c}{ Description } \\
\hline Week 1 & $\begin{array}{l}\text { Passive one-end proximal sliding exercise to the peroneal nerve - knee flexion \& extension movement } \\
\text { performed by maintaining plantar-flexion of the ankle. }\end{array}$ \\
Week 2 & $\begin{array}{l}\text { Passive one-end distal sliding exercise to the peroneal nerve - ankle dorsiflexion to plantar flexion } \\
\text { movement performed by maintaining hip \& knee in a flexed position. }\end{array}$ \\
Week 3 & $\begin{array}{l}\text { Passive two-end proximal tension exercise to the peroneal nerve }- \text { knee extension and neck flexion } \\
\text { movement performed by maintaining plantar flexion of the ankle. }\end{array}$ \\
Weeks $4,5 \& 6$ & $\begin{array}{l}\text { In sitting position, active two-end peroneal nerves sliding exercise to the peroneal nerve }- \text { instructed } \\
\text { to do active tension techniques by doing plantar flexion and inversion of the ankle with neck flexion } \\
\text { movement respectively } \times 2 .\end{array}$ \\
\hline
\end{tabular}

In all rehabilitation sessions, NDT was carried out without producing pain symptoms. These movements interchanged at a rate of around $2 \mathrm{~s}$ for every cycle, i.e. extension (one second) and flexion (one second) (Butler 2005; Nee \& Butler 2006; Shacklock 2005; Villafa et al. 2013). While undergoing the 6-week management process, the subjects from Group A received SP intervention in addition to NDT and Group B had undergone a six-week SP only. The post-intervention measurements were completed at the end of week 3, week 6 and week 12 .

\section{STATISTICAL ANALYSIS}

All statistical analysis was done by using the software package SPSS 22.0 for window version. Mean and standard deviation of all variables were calculated. The level of significance was set at $p<0.05$. Data normality was tested using the Shapiro-Wilk test. Obtained data were analyzed using Repeated Measures Analysis of variance (ANOVA) to examine the interaction effects of time (baseline, mid-intervention, post-intervention and follow-up) and between-subject factors (Intervention Group A and Intervention Group B). Bonferroni post-hoc 
tests were carried out in the cases of a mean difference observed on criterion measures to determine which group pair was highest among others.

\section{RESULTS}

The results of the study were analyzed with the subjects who underwent NDT and SP Intervention (Group A) and SP Intervention only (Group B). The Repeated Measures ANOVA result showed that the Mauchly's test of sphericity had not been violated, $\mathrm{p}=>0.05$ (Table 2).

TABLE 2. Analysis of variance (ANOVA) for dependent variables

\begin{tabular}{|c|c|c|c|c|c|c|c|c|c|c|c|c|}
\hline \multirow[t]{3}{*}{ Variables } & \multirow{3}{*}{$\begin{array}{c}\text { Approx. } \\
\text { Chi- } \\
\text { square } \\
\chi^{2}(5)\end{array}$} & \multirow[t]{3}{*}{$P$} & \multirow{3}{*}{$\begin{array}{c}\text { F-Value, } \\
\text { df }\end{array}$} & \multicolumn{3}{|c|}{ Time } & \multicolumn{3}{|c|}{ Group } & \multicolumn{3}{|c|}{ Time* group } \\
\hline & & & & F-ratio & $\mathrm{P}$ & $\eta p 2$ & F-ratio & $\mathrm{P}$ & $\eta p 2$ & F-ratio & $\mathrm{P}$ & $\eta p^{2}$ \\
\hline & & & & & value & & & value & & & value & \\
\hline VAS & 16.59 & 0.006 & $(1.98,36)$ & 132.697 & $<.001$ & 0.98 & 0.315 & 0.585 & 0.026 & 1.289 & 0.294 & 0.10 \\
\hline FADI & 48.22 & $<.001$ & $(1.148,36)$ & 4701.14 & $<.001$ & 0.62 & 0.691 & 0.422 & 0.054 & 149.62 & 0.470 & 0.05 \\
\hline Y-Balance & 40.90 & $<.001$ & $(1.409,36)$ & 16.42 & $<.001$ & 0.58 & 1.421 & 0.256 & 0.106 & 24.222 & 0.557 & 0.39 \\
\hline Knee ROM & 18.058 & .003 & $(1.498,36)$ & 62.232 & $<.001$ & 0.84 & 0.239 & 0.634 & 0.020 & 2.052 & 0.165 & 0.15 \\
\hline PL(peak activity) & 5.447 & 0.37 & $(3,36)$ & 25.727 & $<.001$ & 0.68 & 0.504 & 0.491 & 0.04 & 0.735 & 0.538 & 0.06 \\
\hline TA(peak & 5.771 & 0.33 & $(3,36)$ & 17.563 & $<.001$ & 0.59 & 0.525 & 0.483 & 0.042 & 0.764 & 0.522 & 0.06 \\
\hline activity) & & & & & & & & & & & & \\
\hline PL (mean value) & 7.651 & 0.18 & $(3,36)$ & 89.930 & $<.001$ & 0.88 & 0.191 & 0.669 & 0.016 & 0.354 & 0.787 & 0.03 \\
\hline TA (mean value) & 8.120 & 0.15 & $(3,36)$ & 199.032 & $<.001$ & 0.94 & 1.283 & 0.279 & 0.097 & 0.143 & 0.933 & 0.01 \\
\hline
\end{tabular}

VAS: Visual Analogue Scale; FADI: Functional Ankle Disability Index; Knee ROM: Knee Range of Motion; PL: Peroneus Longus; TA: Tibialis Anterior

\section{PAIN SCORE (VISUAL ANALOGUE SCALE)}

The pain score results showed a significant reduction between the interventions from week 3 to week 6 ( $F$ $(1.98,36)=132.697, \mathrm{p}<0.001, \eta \mathrm{p} 2=.98)($ Table 2). Post hoc test using the Bonferroni correction showed that the intervention elicited a slight reduction in pain score from baseline to 3 weeks and 6 weeks of intervention $(4.5 \pm$ $1.01,2.78 \pm 1.47$ and $0.85 \pm 1.40)$ respectively, which was statistically significant $(\mathrm{p}<0.001)$. However, there was no statistically significant improvement observed between week 6 and week 12 pain scores following postintervention. Therefore, the study results demonstrated that the combined NDT+SP program until week 6 resulted in significant reduction of pain score, however not after 6 weeks of intervention. Conversely, no significant time and group effects were observed between the NDT+SP and SP participants though pain was equally progressed in both the groups (Table 3 ). 
TABLE 3. Bonferroni post-hoc test for dependent variables

\begin{tabular}{|c|c|c|c|c|c|c|c|c|}
\hline & \multicolumn{4}{|c|}{ GROUP A (NDT+SP) } & \multicolumn{4}{|c|}{ GROUP B (SP) } \\
\hline & Baseline & $\begin{array}{c}\text { Mid- } \\
\text { Intervention }\end{array}$ & $\begin{array}{c}\text { Post- } \\
\text { Intervention }\end{array}$ & Follow-up & Baseline & $\begin{array}{c}\text { Mid- } \\
\text { Intervention }\end{array}$ & $\begin{array}{c}\text { Post- } \\
\text { Intervention }\end{array}$ & Follow-up \\
\hline \multirow[t]{2}{*}{ VAS } & $4.5 \pm$ & $2.63 \pm$ & $0.50 \pm$ & $0.25 \pm$ & $4.67 \pm$ & $3.00 \pm$ & $1.33 \pm$ & $0.17 \pm$ \\
\hline & $0.93^{\mathrm{a}, \mathrm{b}, \mathrm{c}}$ & $1.41^{\mathrm{d}, \mathrm{e}}$ & $1.41^{\mathrm{f}}$ & 0.71 & 1.21 & 1.67 & 1.37 & 0.41 \\
\hline \multirow[t]{2}{*}{ FADI } & $104.75 \pm$ & $121.75 \pm$ & $130.25 \pm$ & $135.50 \pm$ & $114.33 \pm$ & $124.83 \pm$ & $132.33 \pm$ & $135.67 \pm$ \\
\hline & $25.98^{\mathrm{b}, \mathrm{c}}$ & $11.03^{\mathrm{d}, \mathrm{e}}$ & $6.27^{\mathrm{f}}$ & 0.93 & 11.00 & 5.88 & 3.20 & 0.82 \\
\hline \multirow[t]{2}{*}{ Y-Balance } & 74.77 & $81.23 \pm$ & $87.34 \pm$ & $87.89 \pm$ & $70.82 \pm$ & $75.85 \pm$ & $79.31 \pm$ & $80.74 \pm$ \\
\hline & $\pm 15.47^{\mathrm{a}, \mathrm{b}, \mathrm{c}}$ & $11.88^{\mathrm{e}}$ & 9.23 & 8.80 & 7.34 & 7.64 & 9.14 & 9.07 \\
\hline \multirow[t]{2}{*}{ Knee ROM } & $14.72 \pm$ & $9.23 \pm$ & $3.10 \pm$ & $3.03 \pm$ & $13.71 \pm$ & $10.19 \pm$ & $6.41 \pm$ & $3.20 \pm$ \\
\hline & $6.96^{\mathrm{a}, \mathrm{b}, \mathrm{c}}$ & $4.28^{\mathrm{d}, \mathrm{e}}$ & 1.91 & 1.70 & 4.18 & 2.88 & 3.14 & 1.61 \\
\hline PL(peak & $85.48 \pm$ & $149.03 \pm$ & $137.59 \pm$ & $157.42 \pm$ & $83.29 \pm$ & $170.60 \pm$ & $132.40 \pm$ & $161.36 \pm$ \\
\hline activity) & $16.30^{\mathrm{a}, \mathrm{b}, \mathrm{c}}$ & 41.50 & 16.50 & 12.89 & 21.60 & 28.94 & 11.08 & 36.64 \\
\hline TA(peak & $152.66 \pm$ & $139.17 \pm$ & $169.19 \pm$ & $196.04 \pm$ & $137.49 \pm$ & $123.53 \pm$ & $178.52 \pm$ & $193.52 \pm$ \\
\hline activity) & $12.81^{\mathrm{b}, \mathrm{c}}$ & $24.75^{\mathrm{d}, \mathrm{e}}$ & 36.32 & 37.70 & 20.57 & 16.42 & 28.37 & 20.12 \\
\hline PL (mean & $18.74 \pm$ & $20.75 \pm$ & $36.18 \pm$ & $38.96 \pm$ & $17.58 \pm$ & $22.70 \pm$ & $36.07 \pm$ & $39.61 \pm$ \\
\hline value) & $1.78^{\mathrm{b}, \mathrm{c}}$ & $4.57^{\mathrm{d}, \mathrm{e}}$ & 2.31 & 5.14 & 2.45 & 2.67 & 5.66 & 3.97 \\
\hline TA (mean & $27.21 \pm$ & $29.88 \pm$ & $59.12 \pm$ & $58.71 \pm$ & $27.0 \pm$ & $31.76 \pm$ & $60.28 \pm$ & $60.51 \pm$ \\
\hline value) & $2.24^{b, c}$ & $4.35^{\mathrm{d}, \mathrm{e}}$ & 2.45 & 5.21 & 3.46 & 5.55 & 4.24 & 7.14 \\
\hline
\end{tabular}

${ }^{a}$ significant difference from baseline to mid-intervention, ${ }^{b}$ significant difference from baseline to post-intervention, ${ }^{\mathrm{c}}$ significant difference from baseline to follow up, ${ }^{\mathrm{d}}$ significant difference from mid-intervention to post-intervention, ${ }^{\mathrm{e}}$ significant difference from mid-intervention to follow up, ${ }^{\mathrm{f}}$ significant difference from post-intervention to follow up significance was set as $\mathrm{p}<0.05$

\section{FUNCTIONAL ANKLE DISABILITY INDEX (FADI)}

The FADI score showed a significant improvement between the interventions time interval from week 3 until week 12 (F (1.148, $36=4701.14), \mathrm{p}<0.001$, $\eta \mathrm{p} 2=.62)$ (Table 2). Post hoc tests using the Bonferroni correction showed that the intervention elicited an improvement in FADI from baseline to 3,6 and 12 weeks of intervention $(108.85 \pm 20.83,123.07 \pm 9.01$ and $131.14 \pm 5.12$ and $135.57 \pm 0.85)$, respectively, which was statistically significant $(\mathrm{p}<0.05)$. However, no significant time and group effect was observed among the NDT+SP and SP group participants though the ankle stability was progressed equally (Table 3 ).

\section{Y-BALANCE}

The Y-balance score over the injured leg showed a significant improvement between the intervention from week 3 until week 12 F $(1.409,36)=16.42$, p $<0.001$, $\eta p 2=.58)$ (Table 2). Post hoc tests using the Bonferroni correction showed that the intervention elicited an improvement in injured leg balance from baseline to 3 weeks, 6 weeks and 12 weeks of intervention (73.077 $\pm 12.39,78.92 \pm 10.30,83.89 \pm 9.74$ and $84.82 \pm$ 9.31), respectively, which was statistically significant $(\mathrm{p}<0.05)$. However, no significant difference was observed between week 3 and week $6(p=0.068)$ and between week 6 and week $12(p=0.077)$. On the other hand, no significant time and group effects were observed between the NDT + SP and SP group participants though the dynamic balance progressed equally (Table 3 ).

\section{KNEE EXTENSION ROM}

Analysis of knee extension ROM score over the injured leg showed a significant improvement following with intervention from week 3 until week 12 (F $(1.498,36)$ $=62.232, \mathrm{p}<0.001, \eta \mathrm{p} 2=.84)$ (Table 2). Post hoc 
tests using the Bonferroni correction showed that the intervention elicited an improvement in injured leg knee extension ROM from baseline to 3 weeks, 6 weeks and 12 weeks of intervention $(14.28 \pm 5.74,9.64 \pm 3.64$, $4.52 \pm 2.93$ and $3.10 \pm 1.59$ ), respectively, which was statistically significant $(\mathrm{p}<0.05)$. However, no significant difference observed between week 6 and week 12 $(p=0.079)$. Conversely, no significant time and group effect were observed between the NDT+SP and SP group participants though the knee extension ROM progressed equally (Table 3 ).

\section{EMG -PERONEUS LONGUS (PL)}

The EMG peak value - PL score over the injured leg showed a significant improvement between time of intervention from week 3 , week 6 and week 12 (F $(3,36)=25.727, \mathrm{p}<0.001, \eta p 2=.68)$ (Table 2). Post hoc tests using the Bonferroni correction showed that the intervention elicited an improvement in injured leg PL peak value from baseline to 3 weeks, 6 weeks and 12 weeks of intervention $(84.53 \pm 17.99,158.27 \pm$ $37.04,135.36 \pm 14.17$ and $159.10 \pm 24.69)$ respectively, which was statistically significant $(\mathrm{p}<0.05)$. However, no significant difference observed between week 3 and week $6(\mathrm{p}=0.234)$ and between week 6 and week $12(p=0.090)$. On the other hand, no significant time and group effect was observed among the NDT+SP and SP group participants, which indicates the PL peak value equally progressed (Table 3). Conversely, EMG mean value of PL scores over the injured leg showed a significant improvement after 6 weeks of intervention $(\mathrm{F}(3,36)=89.93, \mathrm{p}<0.001, \eta \mathrm{p} 2=.88)($ Table 2$)$. Post hoc tests using the Bonferroni correction showed that the intervention elicited an improvement injured leg PL mean value from baseline to 6 weeks of intervention $(18.24 \pm 2.09$ and $36.13 \pm 3.90)$, respectively, which was statistically significant $(\mathrm{p}<0.05)$. However, no significant difference was observed between baseline and after 3 weeks $(21.58 \pm 3.8, \mathrm{p}=0.081)$; also observed no difference between week 6 and week $12(p>0.05)$. Equally, no significant time and group effect was observed among the participants (Table 3).

\section{EMG -TIBIALIS ANTERIOR (TA)}

The EMG peak value - TA score over the injured leg showed a significant improvement after 6 weeks of intervention $(\mathrm{F}(3,36)=17.563, \mathrm{p}<0.001, \eta \mathrm{p} 2=.59)$ (Table 2). Post hoc tests using the Bonferroni correction showed that the intervention elicited an improvement in injured leg TA peak value from baseline to 6 and 12 weeks of intervention $(146.16 \pm 17.65,173.18 \pm 32.29$, and $194.95 \pm 30.37)$ respectively, which was statistically significant $(\mathrm{p}<0.05)$. However, no significant difference was observed between baseline and week $3(p=0.361)$ and between week 6 and week $12(p=0.214)$. However, no significant time and group effect was observed among the NDT+SP and SP group though the participants indicate TA peak value progressed equally (Table 3 ). Conversely, EMG mean value of the TA score over the injured leg showed a significant improvement only after 6 weeks of intervention $(\mathrm{F}(3,36)=199.032, \mathrm{p}<0.001$, $\eta p 2=.94)$ (Table 2 ). Post hoc tests using the Bonferroni correction showed that the intervention elicited an improvement over injured leg TA mean value from baseline to 6 weeks and 12 weeks of intervention (27.13 $\pm 2.70,59.61 \pm 3.24$ and $59.48 \pm 5.92$ ), respectively, which was statistically significant $(\mathrm{p}<0.05)$. However, no significant difference was observed between baseline and after 3 weeks $(30.68 \pm 4.7, \mathrm{p}=0.081)$; also observed no difference between week 6 and week 12 ( $\mathrm{p}>0.05)$. Conversely, no significant time and group effect was observed among the participants (Table 3 ).

\section{DISCUSSION}

IAS is the most widely recognized musculoskeletal injury in sports. The present study examined the effect of Neurodynamic Technique and Standard Physiotherapy on pain score, dynamic balance, peroneal longus and tibialis anterior muscle activation response, knee range of motion (ROM) and functional ankle disability index (FADI) among young Malaysian athletes. This study confirmed that participants in both the group had progressed during the rehabilitation from baseline to the follow-up sessions. This study observes variables from the two groups gradually improved on the injured leg in the NDT+SP and SP showed better results in pain score, FADI score, dynamic balance, Knee extension ROM, peroneal longus, and tibialis anterior muscle activation response. The injury was reported on the dominant right side of the leg (right leg) among the majority of the participants in this trial. Likewise, a study among elite female soccer players has evidenced the incidence of ankle and knee injuries over their dominant legs particularly in contact injuries (Faude et al. 2006). Kang and Ramalingam (2018), however, reported a contradictory result among Malaysian badminton players as the most common location for these lower extremity injuries was the knee $(37.1 \%)$, followed by ankle $(28.3 \%)$ injury in non-contact sports. On the other hand, the present study interventions effect and improvements in FADI scores among participants in both the groups were associated with previous reported studies on CAI (Webster \& Gribble 2010; Wikstrom et al. 2009). Apparently, the participants with minimal training in sports might have less dynamic balance scores and similarly the researchers reported CAI participants to have experienced a deficit in dynamic balance compared with healthy ankles (Olmsted et al. 2002; Sefton et al. 2009). Until week 6, participants in Group A managed with NDT+SP program elicited a significant reduction 
in pain score, but not after 6 weeks of intervention. However, the study by Bleakley et al. (2010) reported no reduction in participants' pain after overall ankle rehabilitation during the rest and activity which shows better intervention effect in this study. The participants' pre-intervention surface EMG muscle activation (PL and TA) response showed changes over the injured side remarkably follow with post-intervention. Remarkably, the participants' peroneal longus peak activation was observed to be less in the baseline (Figure 2).

Similarly, the study by Santilli (2005) reported decreased activation of peroneus longus muscle in the

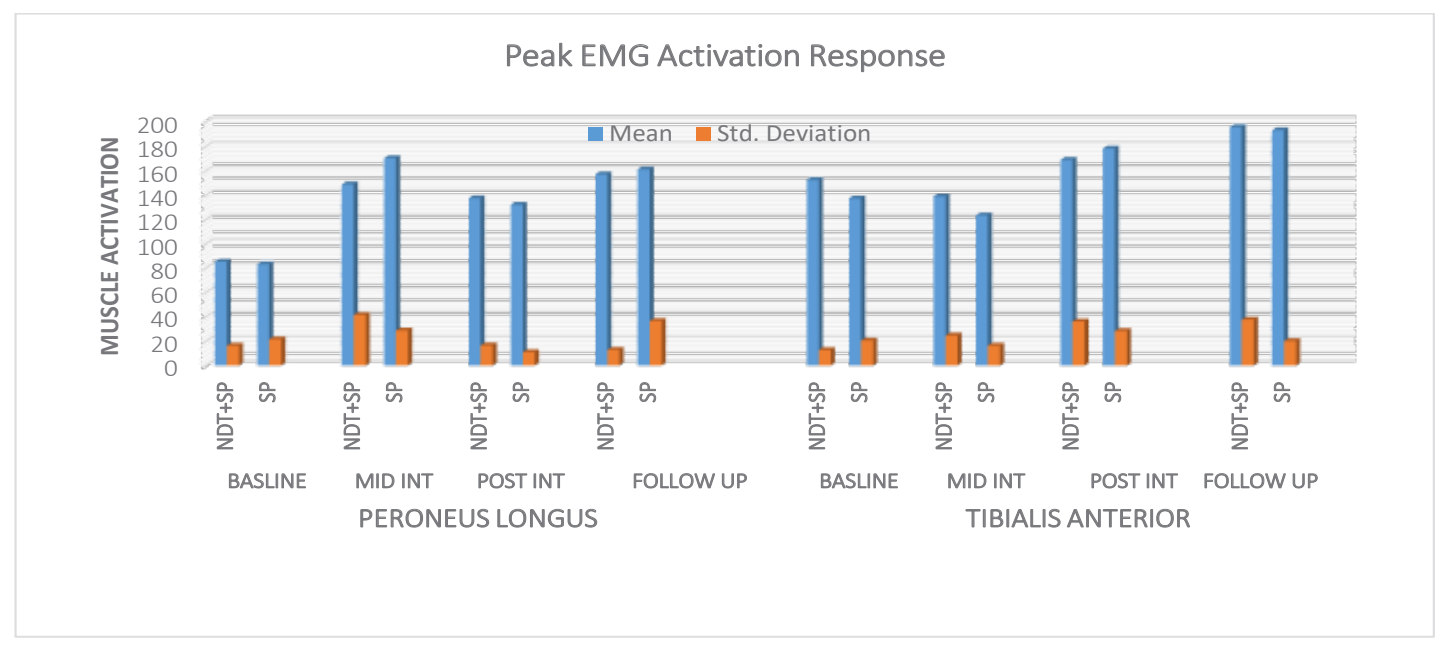

FIGURE 2. Peroneus longus and tibialis anterior muscle peak activation during walking $2 \mathrm{~km} / \mathrm{h}$

injured leg in the stance phase of gait. On the other hand, studies addressed in walking, muscle co-activation might increase the EMG (PL and TA) amplitudes (Bavdek et al. 2018; Hoch \& McKeon 2014; Hopkins et al. 2012). Likewise, the studies reported the peroneus longus might experience an inability to generate adequate eversion muscle contractions during stance phase of gait, which might be related to the risk of multiple ankle sprains in common activities of daily living which had progressed after the intervention (Buchanan et al. 2008; Docherty et al. 2005). However, our study reported progression in ankle stability among the participants in both FAI and control groups.

Studies showed that NDT is a mechanical treatment of neural tissues in physiotherapy, which has been in existence for quite some time (Docherty et al. 2005;

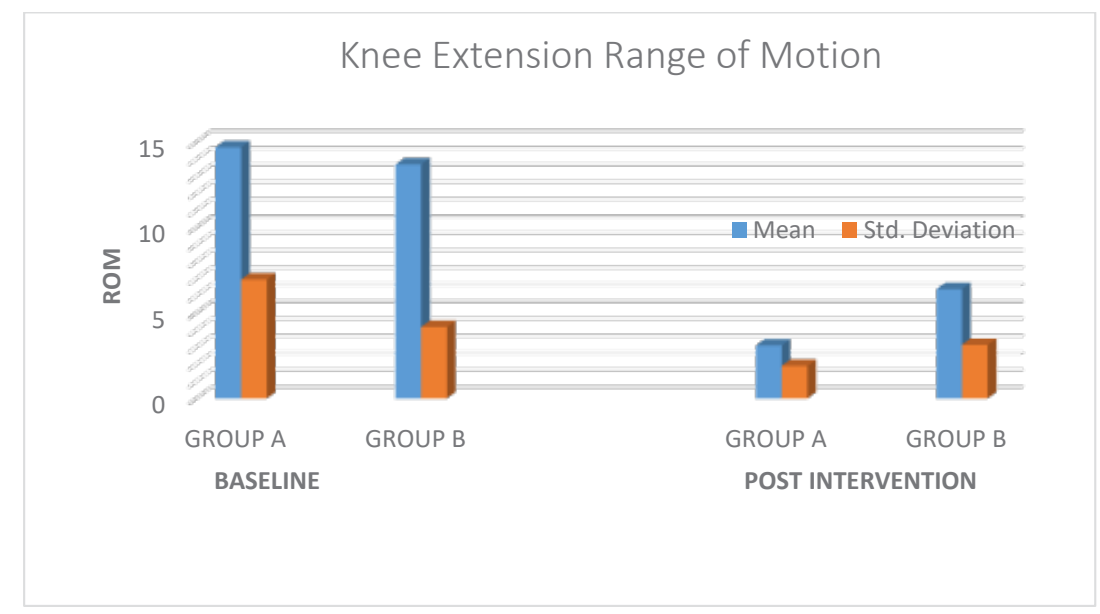

FIGURE 3. Bar diagram shows mean and standard deviation of baseline and post - intervention Knee Extension lack of movement in active slump sitting 
Shacklock 2005). According to Khalid et al. (2008), peroneal nerve assessment is necessary for the inversion ankle sprain participants and Mitsiokapa et al. (2016) reported the limited terminal knee extension among the injured ankle participants when comparing with uninjured ankle by using active slump test. Sensibly, the knee extension ROM has improved among participants in group A after receiving a post application of NDT when comparing with SP. According to the obtained results (Figure 3), knee extension ROM in the group A mean shows better result in comparison with Group B. However, the SP also showed relative improvement among participants.

\section{LIMITATION}

Though this study has limitations of having a small number of participants, the findings show potential outcome by having significant results. The present study does suggest for future research with more participants to see the effect of NDT in repeated inversion ankle sprains. Besides, to include various foot shapes as the variables in assessing the foot center of pressure. Specifically, the eversion muscle peroneus brevis SEMG response is another limiting factor that needs to be considered in future studies and to include additional lower leg muscles for investigating the dynamic response among FAI participants.

\section{CONCLUSION}

The findings of this study show improvement in both groups in dynamic balance, pain score, peroneal longus and tibialis anterior muscle activation response, knee ROM, and FADI. Together with standard physiotherapy intervention, the Neurodynamic Technique shows safe and similar effects between the variables. Further, it strongly recommends the neurodynamic technique to be part of the ankle rehabilitation protocol to prevent repetitive IAS.

\section{ACKNOWLEDGEMENTS}

The authors acknowledge Institut Sukan Negara (ISN) for Funding through research Grant (ISNRP 17/2015) and granting permission to utilize the facilities to carry out this project successfully. Besides, we acknowledge the ISN doctors, Physiotherapist and Biomechanist for their continuous support by referring participants to the trail. Also, we extend our thanks to English Proof Reader Mr. Uvaraj Subramani for his support in proof reading this article.

\section{REFERENCES}

Bavdek, R., Zdolšek, A., Strojnik, V. \& Dolenec, A. 2018. Peroneal muscle activity during different types of walking. Journal of Foot and Ankle Research 11: 50.

Bleakley, C.M., O'Connor, S.R., Tully, M.A., Rocke, L.G., MacAuley, D.C., Bradbury, I., Keegan, S. \& McDonough, S.M. 2010. Effect of accelerated rehabilitation on function after ankle sprain: Randomised controlled trial. BMJ 2010: 340.

Buchanan, A.S., Docherty, C.L. \& Schrader, J. 2008. Functional performance testing in participants with functional ankle instability and in a Healthy Control Group. Journal of Athletic Training 43(4): 342-346.

Bullock-Saxton, J.E. 1995. Sensory changes associated with severe ankle sprain. Scand. J. Rehabil. Med. 27(3): 161-167.

Butler, S.D. 2005. The Neurodynamic Techniques: A Definitive Guide from the Noigroup Team. Adelaide: Noigroup Publications.

Castellote-Caballero, Y., Valenza, M.C., Puentedura, E.J., Fernández-de-las-Peñas, C. \& Alburquerque-Sendín, F. 2014. Immediate effects of neurodynamic sliding versus muscle stretching on hamstring flexibility in subjects with short hamstring syndrome. Journal of Sports Medicine 2014: 127471.

Coppieters, M.W., Stappaerts, K.H., Everaert, D.G. \& Staes, F.F. 2001. Addition of test components during neurodynamic testing: Effect on range of motion and sensory responses. Journal of Orthopaedic \& Sports Physical Therapy 31(5): 226-237.

Coughlan, G. \& Caulfield, B. 2007. A 4-week neuromuscular training program and gait patterns at the ankle joint. Journal of Athletic Training (National Athletic Trainers' Association) 42(1): 51-59.

Docherty, C.L., Arnold, B.L., Gansneder, B.M., Hurwitz, S. \& Gieck, J. 2005. Functional-performance deficits in volunteers with functional ankle instability. Journal of Athletic Training 40(1): 30-34.

Faude, O., Junge, A., Kindermann, W. \& Dvorak, J. 2006. Risk factors for injuries in elite female soccer players. British Journal of Sports Medicine 40(9): 785-790.

Garrick, J.G. \& Requa, R.K. 1988. The epidemiology of foot and ankle injuries in sports. Clinics in Sports Medicine 7(1): 29-36.

Gutierrez, G.M., Kaminski, T.W. \& Douex, A.T. 2009. Neuromuscular control and ankle instability. $P M$ and $R$. 1(4): 359-365

Hertel, J. 2002. Functional anatomy, pathomechanics, and pathophysiology of lateral ankle instability. Journal of Athletic Training 37(4): 364-375.

Hoch, M.C. \& McKeon, P.O. 2014. Peroneal reaction time after ankle sprain: A systematic review and meta-analysis. Medicine and Science in Sports and Exercise 46(3): 546556.

Hopkins, J.T., Coglianese, M., Glasgow, P., Reese, S. \& Seeley, M.K. 2012. Alterations in evertor/invertor muscle activation and center of pressure trajectory in participants with functional ankle instability. Journal of Electromyography and Kinesiology 22(2): 280-285.

Kang, A.L. \& Ramalingam, V. 2018. Risk factors for lower extremity injuries in young badminton players. Scientia Medica 28(2): 5.

Khalid, R., Millar, T., Khalid, R., Peroneal, T.M. \& Internet, T. 2008. Peroneal nerve palsy following an ankle sprain: Case report. European Journal of Orthopaedic Surgery \& Traumatology 15(1): 26507641.

Malliaropoulos, N., Ntessalen, M., Papacostas, E., Longo, U.G., Maffulli, N., Malliaropoulos, N. \& Papacostas, E. 2009. Reinjury after acute lateral ankle sprains in elite track and field athletes. The American Journal of Sports Medicine 37: 1755-1761. 
Mattacola, C.G. \& Dwyer, M.K. 2002. Rehabilitation of the ankle after acute sprain or chronic instability. Journal of Athletic Training 37(4): 413-429.

McKay, G.D. 2001. Ankle injuries in basketball: Injury rate and risk factors. British Journal of Sports Medicine 35(2): 103-108.

McKeon, P.O. \& Mattacola, C.G. 2008. Interventions for the prevention of first time and recurrent ankle sprains. Clinics in Sports Medicine 27(3): 371-382.

Mitsiokapa, E., Mavrogenis, A.F., Drakopoulos, D., Mauffrey, C. \& Scarlat, M. 2016. Peroneal nerve palsy after ankle sprain: An update. European Journal of Orthopaedic Surgery \& Traumatology: Orthopedie Traumatologie 27(1): 53-60.

Murphy, D.F., Connolly, D.A.J. \& Beynnon, B.D. 2003. Risk factors for lower extremity injury: A review of the literature. British Journal of Sports Medicine 37(1): 13-29.

Nee, R.J. \& Butler, D. 2006. Management of peripheral neuropathic pain: Integrating neurobiology, neurodynamics, and clinical evidence. Physical Therapy in Sport 7(1): 36-49.

O’Neill, P.J., Parks, B.G., Walsh, R., Simmons, L.M. \& Miller, S.D. 2007. Excursion and strain of the superficial peroneal nerve during inversion ankle sprain. Journal of Bone and Joint Surgery - Series A 89(5): 979-986.

Oda, K., Ogaki, R., Murakami, K., Kurosawa, T., Yamaguchi, T., Takahashi, Y. \& Miyakawa, S. 2019. Effects of functional ankle instability on collegiate female football players' performances. Journal of Sports Science 7: 1-5.

Olmsted, L.C., Carciat, C.R., Hertel, J. \& Shultz, S.J. 2002. Efficacy of the star excursion balance tests in detecting reach deficits in subjects with chronic ankle instability. Journal of Athletic Training 37(4): 501-506.

Pahor, S. \& Toppenberg, R. 1996. An investigation of neural tissue involvement in ankle inversion sprains. Manual Therapy 1(4): 192-197.

Ramalingam, V., Sundar, V. \& Joseph, S. 2018. Neurodynamic technique on functional ankle instability: A case report. Journal of Clinical and Diagnostic Research 12(4): YD01YD04

Santilli, V. 2005. Peroneus longus muscle activation pattern during gait cycle in athletes affected by functional ankle instability: A surface electromyographic study. American Journal of Sports Medicine 33(8): 1183-1187.

Sefton, J.E.M., Hicks-Little, C.A., Hubbard, T.J., Clemens, M.G., Yengo, C.M., Koceja, D.M. \& Cordova, M.L. 2009. Sensorimotor function as a predictor of chronic ankle instability. Clinical Biomechanics 24(5): 451-458.

Shacklock, M. 2005. Clinical Neurodynamics. Netherlands: Elsevier Health Sciences.
Shaffer, S.W., Teyhen, D.S., Lorenson, C.L., Warren, R.L., Koreerat, C.M., Straseske, C.P. \& Childs, J.D. 2015. Y-balance test: A reliability study involving multiple raters. Mil. Med. 178(11): 1264-1270.

Shariff, A.H., George, J. \& Ramlan, A.A. 2009. Musculoskeletal injuries among Malaysian badminton players. Singapore Medical Journal 50(11): 1095-1097.

Türker, H., Sözen, H., Feger, M.A., Hertel, J., Balakrishnan, R., Ellanchezlian, E. \& Clinic, B.O. 2016. Difference in response latency of the peroneus longus between the dominant and nondominant legs. Journal of Athletic Training 37(1): 321332.

Villafa, J.H., Pillastrini, P. \& Borboni, A. 2013. Manual therapy and neurodynamic mobilization in a patient with peroneal nerve paralysis: A case report. Journal of Chiropractic Medicine 12(3): 176-181.

Webster, K.A. \& Gribble, P.A. 2010. Functional rehabilitation interventions for chronic ankle instability: A systematic review. Journal of Sport Rehabilitation 19(1): 98-114

Wikstrom, E.A., Hubbard-Turner, T. \& McKeon, P.O. 2013. Understanding and treating lateral ankle sprains and their consequences: A constraints-based approach. Sports Medicine 43(6): 385-393.

Wikstrom, E A., Tillman, M.D., Chmielewski, T.L., Cauraugh, J.H., Naugle, K.E. \& Borsa, P.A. 2009. Self-assessed disability and functional performance in individuals with and without ankle instability: A case control study. Journal of Orthopaedic \& Sports Physical Therapy 39(6): 458-467.

Vinodhkumar Ramalingam*

Faculty of Health and Life Sciences

INTI International University

71800 Nilai, Negeri Sembilan

Malaysia

Viswanath Sundar \& Saju Joseph

Department of Biomechanics

National Sports Institute

53000 Kuala Lumpur, Federal Territory

Malaysia

*Corresponding author; email: vinodh.ramalingam@newinti. edu.my

Received: 14 July 2019

Accepted: 31 January 2020 